\title{
Occupying New Spaces: the "Digital Turn" of Afro-Brazilian Religions During the Covid-19 Outbreak
}

\author{
Giovanna Capponi ${ }^{1} \cdot$ Patrício Carneiro Araújo $^{2}$ (D)
}

Received: 22 June 2020 / Accepted: 18 September 2020/Published online: 29 September 2020

(C) Springer Nature Switzerland AG 2020

\begin{abstract}
This paper intends to analyze how Afro-Brazilian religious minorities (like Candomblé and Umbanda) are responding to the Covid-19 crisis in Brazil both at a religious and political level. Drawing a comparison between the reactions of Neo-Pentecostal churches and Afro-Brazilian religions, we will describe how the pandemic outbreak and the social distancing measures allowed Afroreligious practitioners to occupy new online spaces. In doing so, these religions found new modalities of practising rituals and transmitting sacred knowledge in the digital world. Despite the fundamental importance of bodily engagement in these religious expressions, Candomblé and Umbanda practitioners are increasing their presence online through producing different types of pedagogical, educational and ritual contents. While on the one hand, this new content aims at promoting social distancing and sanitary precautionary measures, on the other hand, it involves a restructuring of the dynamics of legitimation and power that are present in Afro-religious social structures. We will analyze these changing dynamics as consequences of the "crisis of the body" that resulted from the lockdown measures.
\end{abstract}

Keywords Afro-Brazilian religions · Neo-Pentecostalism · Covid-19 $\cdot$ Religion and media $\cdot$ Body and religion

Giovanna Capponi

giovanna.capponi@gmail.com

Patrício Carneiro Araújo

patricio.carneiroa@gmail.com

1 Département de la Recherche et de l'Enseignement, Musée du quai Branly, Paris, France

2 Instituto de Humanidades, Universidade da Integração Internacional da Lusofonia Afro-Brasileira (UNILAB), Redenção, CE, Brazil 


\section{Introduction}

The preventive measure of social distancing, implemented in an increasingly rigorous manner by different governments, has largely affected all aspects of citizens' lives, including religious life. In Brazil, the spread of the Covid-19 virus became the cause of numerous political controversies. As it happened in other countries worldwide, the debate was polarized between those who approved the containment measures (put into place by the state governments) and those who supported the position of the federal government, which continued to deny the entity of the epidemiological crisis. Political disputes soon turned into religious disputes since the moment in which the president Bolsonaro declared that Neo-Pentecostal churches should remain open, as, in his view, they provide an essential service for the society (Hartikainen 2020).

Simultaneously, the vast majority of practitioners of Candomblé, Umbanda and other Afro-religious denominations began to cancel events, supporting not only the rules imposed by state governments but also the scientific positions that underscore the seriousness of the pandemic and the need to "stay home". In the occurrence of the pandemic outbreak, Afro-religious leaders and practitioners started to intensify their presence online in an unprecedented way. This profound change impacted the fundamental aspects of these religions like ritual secrecy, hierarchy and legitimization through online media. Moreover, religious discourses started to overlap with scientific discourses in promoting social distancing against the scepticism of the central government. In this paper, we would like to analyze how this "virtual turn", meaning the sudden and increasing use of digital media for religious purposes, intertwines with the new modalities of social and religious interaction imposed by the pandemic outbreak.

In this paper, we drew data from Candomblé and Umbanda houses located mainly in the state of São Paulo and with whom we have been working during several years of fieldwork. The longstanding professional and personal engagements we developed with these religious communities allowed us to follow their online movements and to observe their shifting practices and discourses. Moreover, we also expanded our networks and observed their interactions with fellow terreiros (Afro-Brazilian temples) located in other states, like Rio de Janeiro, Bahia and Ceará. For these reasons, this contribution analyses a general trend of discourses and practices that have been collectively elaborated during the pandemic outbreak, despite the multiple internal conflicts and discrepancies that have emerged between different groups.

\section{From Smallpox to Covid-19: Afro-Brazilian Imaginary on Epidemic Diseases}

Afro-Brazilian religions are a variety of religious expressions of African origin, which were codified in Brazil during the Afro-Atlantic slave trade, between the 16th and 19th centuries. These new religions (called Candomblé, Umbanda, Xangô and other denominations according to their regional varieties) accommodate in their pantheon different deities (called orixás, nkisi, voduns) and spiritual entities of both African and Amerindian origin. Deities are associated with aspects of nature such as fertility, disease/health, natural elements such as rivers and waterfalls, winds and storms, fire and earth, or with specific aspects of social life such as hunting, war, agriculture, metallurgy, commerce and medicine. 
Despite being traditionally more widespread in the Northeast of the country, Umbanda and Candomblé temples are common all throughout Brazil. These religions have expanded and transformed themselves through contact with, and the appropriation and re-appropriation of, elements of Catholicism, spiritism, Amerindian and Amazonian religions. More recently, these religions also had to renegotiate practices and values with traditional African folk religions recently arrived in Brazil from Central America, the Caribbean (Cuba) and the African continent (Nigeria, Benin and Togo).

Candomblé and Umbanda rituals usually take place inside dedicated temples, generally called terreiros, but also with other names like ilê, mansu, zoogodô and inzo, which are generally translated as "house". Temples, which normally also host the private residence of the leading priest(ess), are attended by religious followers during rituals on a weekly or monthly basis. AfroBrazilian rituals involve the worship of the deities in the form of sacrifices, food offerings, ritual chants and dances, and trance possession. These religions also involve elaborate initiation rituals and rites of passage in which the bodily engagement of the novice is seen as an essential feature. Gestures like kissing each other's hands (a form of asking one's blessing), sharing food from the same plate and other forms of physical contact are of fundamental importance in the performing of rituals.

Indeed, in Afro-Brazilian religions, the sacred force (called axé) is passed through bodies, substances and materials, which make the physical presence an essential and preeminent feature. This immanent force is also considered to contribute to the healing and general well-being of religious followers.

One of the most worshipped deities in Brazil, and one that is linked to infectious diseases, is Omolu, also known as Obalúayé, Sapatá, Saponã, Azauane, among other epithets. He is considered a terrible and dangerous deity as it holds power over diseases and healing, and he is especially connected to smallpox and epidemic diseases. Indeed, the name given to the specific rhythm of Omolu invokes fear: opanijé, which means, "He will kill and eat anyone".

Ruling over all kinds of diseases, whether chronic, endemic, epidemic or pandemic, this deity has been referred to by the Brazilian ethnologist Édison Carneiro (1969), as "the doctor of the poor". Precisely for this reason, his worshipping has always been, and it continues to be, surrounded by mysteries, respect and fear.

Afro-religious followers turn to Omolu and other deities connected to healing during time of illness. It is no wonder that during the Covid-19 pandemic in Brazil, the devotion towards him intensified significantly. This devotion has been expressed not only through the performing of ritual offerings but also through new practices within cyberspace. In some cases, priests and priestesses were seen throwing popcorn (food connected to Omolu and in general to healing rites) on the streets, as a way of ritually "disinfecting" the public space, and asking Omolu to cleanse the world from the terrible virus. This notion was also delivered through images shared on social media which depicted Omolu and Ossain (the deity of herbal medicine) in the act of healing the planet from the pandemic. Here, the symbols connected to these deities and their powers are specifically related to the physical and the spiritual healing in the present context, rather than to more symbolic or abstract notions of body purity and spiritual cleansing. 
In the following sections, we will describe how the online presence of AfroBrazilian religions became increasingly important to the point of suspending and transforming the fundamental role of the body in these religious contexts.

\section{Digital Media and the Body: Political and Religious Conflicts}

Political and religious conflicts between Neo-Pentecostal churches and Afro-Brazilian religions have intensified in recent decades, both for mundane and ethical reasons, such as access to public space for religious events and regulations on ritual animal slaughter (da Silva 2007). The pandemic outbreak broadly exposed two different approaches, both a political and religious level.

Since the beginning of the Covid-19 crisis, many Neo-Pentecostal authorities have denied the suspension of religious services. Indeed, Neo-Pentecostal churches currently compose the basis of the government's electorate, and famous pastors have been openly shaping and influencing Bolsonaro's political stances. The government's minimizing attitude towards the pandemic is also supported by the industrial sector, which fears the economic damages that would be caused by a generalized lockdown.

Religious leaders like Edir Macedo (Universal Church of the Kingdom of God, later UCKG) and Silas Malafaia (Assemblies of God) strongly refused to adhere to the policies of social isolation and closure of churches. ${ }^{1}$ Pastors circulated messages in their blogs and social networks asking their followers not to fear the virus, adding that God would protect those who have faith. ${ }^{2}$ In a video published in the media channels of the UCKG, Edir Macedo even claimed that the virus was nothing more than a tactic of Satan to keep the faithful away from the churches. ${ }^{3}$ In Macedo's logic, any authority that encourages the closure of churches would be advertently at the service of Satan. Therefore, Neo-Pentecostal followers should continue to attend public worship. Pastor Silas Malafaia adopted a similar posture. Closing churches, in their words, would mean a lack of confidence in the divine power.

Some religious leaders later produced a video ${ }^{4}$ that went on to circulate widely on social networks, in which they called for a national day of fast and prayer on the 5 th of April 2020. Different Neo-Pentecostal churches and president Bolsonaro participated in this event as a way to combat the virus. ${ }^{5}$ At that time, churches were receiving criticism for promoting religious gatherings and facilitating mass contagion, even if president Bolsonaro still insisted that the virus was not as lethal as reports were claiming. Indeed, the government aligned with the discourse of the Neo-Pentecostal churches and repeatedly tried to relax the rules of social isolation by reopening the religious temples.

One of those pastors who strongly advocated the maintenance of the functioning of the churches during the pandemic, Pastor Silas Malafaia, even said that the religious

\footnotetext{
${ }^{1}$ https://noticias.uol.com.br/saude/ultimas-noticias/redacao/2020/03/14/silas-malafaia-diz-que-nao-vai-fecharigreja-por-causa-do-coronavirus.htm (last accessed 10/08/2020).

2 https://www.instagram.com/tv/B9tk-0bnqel/ (last accessed 10/08/2020).

${ }^{3}$ https://apublica.org/2020/03/megaigrejas-continuam-abertas-e-dizem-que-fe-cura-coronavirus/\#Link1 (last accessed 10/08/2020).

${ }^{4} \mathrm{https}: / /$ www.youtube.com/watch?v=MV7vR1ZX19Q (last accessed 10/08/2020).

${ }^{5}$ https:/www.correiobraziliense.com.br/app/noticia/politica/2020/04/04/interna_politica,842421/bolsonaroconvoca-populacao-a-participar-de-campanha-de-jejum.shtml. (last accessed 10/08/2020).
} 
temples should be considered essential services as they provided necessary psychological support for the population. Despite this pressure, the state and municipal governments maintained the decision to close religious temples during the pandemic, supported in their decision by a sentence of the court of law of the State of São Paulo. ${ }^{6}$

It is important to emphasize that evangelical churches have always been pioneers in the use of new technologies. YouTube channels, television networks, social network accounts and media outreach techniques have always been an integral part of how evangelical churches spread a true "spectacle" of prosperity, efficiency and miracles (Kramer 2005; Mariano 2004). In the past decade, Neo-Pentecostal pastors proudly broadcasted worship sessions in their television networks. They also skilfully managed their social media accounts, posting videos, blog articles and tweets at a rate of several contents per day.

The role of new media and technology in Neo-Pentecostal churches and Charismatic Christianity in Brazil and other countries became a privileged field of study for many scholars (Martini 2020). Birgit Meyer explains how technology media such as lights, microphones, TV and radio broadcasting infrastructures are fundamental features of Pentecostalism in Ghana (2011). The transcendental and its power are lived and experienced through and with these material affordances.

However, despite the availability of a magnificent and well-oiled mediatic infrastructure, during the Covid-19 outbreak, Neo-Pentecostal churches in Brazil highlighted the importance of in-person attendance to show faith and to fight the virus. The reason for this possibility lies in the fact that the Covid-19 crisis represents, in all sectors, a crisis of the body and its potential. Drawing from his fieldwork among Charismatic Christians in Ghana, Bruno Reinhardt (2020) highlights that the technological extensions of religion rely on the combination of the organic body (pastors, prophets, charismatic leaders, ecstatic followers, etcetera) and the mechanical elements (prayer mats, loudspeakers, recorders, etcetera). These features work together and enable religious performance. We could argue that the sudden restrictions applied to the body as one of the fundamental elements of these highly performative religions put the whole system at stake.

In times of social distancing, the crisis of the body imposed a general and sudden transformation in how religious relations are experienced and conceived. This proves to be even more difficult in contexts like Afro-Brazilian religions, where rituals are performed literally around the novice's body. Moreover, in these contexts, the use of technological affordances like videos, photos and lights is considered controversial and sometimes even unsuited to the ceremonial atmosphere (Van de Port 2020).

In religions like Candomblé and Umbanda, almost all ritual processes involve bodily engagement, physical contact and even entailing the exchange of bodily fluids and food between participants. Since the beginning of the Covid-19 crisis in Brazil, videos and live messages from Afro-religious priests and priestesses have begun to appear on social networks. In these videos, Afro-religious authorities gave practical information on health, prevention and social distancing, announcing the temporary suspension of all public ritual activities. Moreover, in their discourses, they suggested hygienic measures such as avoiding kissing each other's hands (a form of ritual greeting) and promoting

\footnotetext{
${ }^{6}$ https://g1.globo.com/sp/sao-paulo/noticia/2020/03/20/coronavirus-justica-de-sp-proibe-missas-e-cultos. ghtml (last accessed 14/09/2020).
} 
the use of masks. Despite generally adhering to the rules of social distancing, the ways in which Candomblé and Umbanda practitioners continued to perform their religious functions and ritual obligations is one of the research topics that could be further investigated. It is also true that in some temples, the rituals were carried out privately and with a restricted number of people. It is the case of terreiros where the members of the religious community coincide with the biological family. In other terreiros, rituals were carried out in a "minimalistic" fashion, with less elaborated food offerings and sacrificial rites that could be prepared and performed by a smaller group. It was also observed that some terreiros chose to keep the events public while adopting security measures such as the use of masks and social distancing between participants. Due to the difficulties in keeping safety and sanitary measures in Umbanda and Candomblé ritual practices, these attempts to keep running the public celebrations were severely criticized by the Afro-religious community, especially on social media. These online disputes often involved religious leaders (but also the followers) and they revolved around what is the most appropriate way to behave and to carry out rituals in such a delicate time. Online controversies are not a new topic in the Afro-religious milieu. Social media have been, for almost a decade, the hotbed for political claims (Capponi and Carneiro Araújo 2015), disputes around secrecy and knowledge transmission (Carneiro Araújo 2016). In this case, online discussions are aiming at criticizing the legitimization of the ritual practice in the present pandemic situation.

Interestingly, the ways in which Afro-religious authorities promote social distancing often overlaps with other values, such as the need to "protect the elders" (a reference to the importance of hierarchy in the religious structures of terreiros) and to respect nature, hinting at the zoonotic origin of the virus. In a similar vein, other followers suggested parallelism between the social and sanitary isolation and the period of ritual seclusion, which marks the initiatic process. In doing so, these practitioners were stressing the introspective characteristics of the religious practice, instead of associating it (as it usually happens) with public festivities, drumming and large crowds of people. Religious values are used to encourage preventive health habits, adding that the deities cannot protect us from the danger of an unbalanced world.

\section{Creating New Virtual Afro-Brazilian Spaces}

While Neo-Pentecostal churches have been active on digital media for over a decade, AfroBrazilian religions have only recently begun to occupy online spaces. To draw an example, the YouTube channel of Edir Macedo of the UCKG counts more than 2400 videos released over 6 years. Conversely, Babá Egbé Leandro, spokesperson of the Axé Oxumaré, one of the traditional Candomble houses of Salvador, started to produce content for his channel only in 2019, at a rate of one video per week. In general, famous pastors invest a large sum of resources in systematizing and managing social media pages, channels and blogs. Conversely, Afro-religious authorities often rely on homemade solutions and a much more fragmented scheme of social media profiles and web addresses.

For a long time, the need to preserve the ritual secrecy (a widespread aspect of initiatic religions) implied a certain reticence to share photos or videos of these practices (Beliso-De Jesús 2015, 5). Indeed, religious leaders who spread ritual knowledge on social networks have been often accused of doing it as a form of self- 
promotion, for money or fame. Since the beginning of the pandemic crisis, many Afroreligious leaders have started to share different types of content on social networks supporting the adoption of confinement measures. However, together with political statements and educational tips, different types of religious contents started to appear.

Both religious authorities and followers began to organize synchronized prayers at certain given times in order to ask for the blessing of Omolu. Some terreiros started to broadcast ritual sessions live on social media platforms, while others organized private sessions through videoconferencing. In some cases, these online sessions allowed more horizontal participation in the social activities of Candomblé and Umbanda communities. Online spaces started to become points of encounter, exchange and oral transmission of knowledge. ${ }^{7}$ At the same time, these new modalities also started to subvert the rigid structure of Afro-Brazilian religions, especially in terms of hierarchy and access to ritual knowledge. Indeed, the popularity of younger priests or priestesses, who are certainly more at ease with the use of new technologies and digital media, is increasing, proportionate with the amount and quality of online content they produce. In this context, these issues directly affect and change how the ritual knowledge is controlled and transmitted by the elders, who find themselves with less power and visibility.

The overestimation of orality in the study of Afro-Brazilian religions has been explored in the work of Lisa Earl Castillo (2008). The author deconstructs the false dichotomy between oral and written transmission of religious knowledge, pointing at the multiple written and photographic records which are produced and circulated within terreiros. Examples include the cadernos, private notebooks where novices note down ritual recipes, sacred chants and other secret details, but also the ethnographic books which are written, read and debated by both academics and religious practitioners (Mason 2002).

Indeed, it is not surprising that videos and sound records also started to be integrated into the Afro-religious milieu. Beliso-De Jesús (2015) analyses how new media technologies, despite multiple controversies and prohibitions, became important learning tools for Santería priests in the transnational context. The author observes that the use of new media in these religions does not function as a form of sacralized mediation between believers and the transcendent, as largely accepted by other scholars in the "media turn" of religious studies (Meyer 2009, 12). Instead, Beliso-De Jesús talks about co-presences pointing at the actual materiality of electric currents, images and sounds that produce bodily reactions and engagements with spirits and entities. These religious experiences are an integral part of the relationship with Santería deities and priests whose voices and movements travel outside Cuba through television screens and records (2015, p. 66).

While still considered fraudulent practices by most Afro-religious followers (in Cuba and in Brazil), synchronous and asynchronous online interactions can be used to guide a ritual at a distance, to attend clients and godchildren in need and even to trigger bodily reactions like trance possession. These modalities are

\footnotetext{
${ }^{7}$ While YouTube videos are aimed at the wider public and are used by religious authorities to disseminate elaborate explanations of myths or teachings about specific aspects of the religious practice, Facebook and Instagram rapidly became the favourite media for live ritual performances, chanting and interactive debates. Instant messaging and videoconference applications like Zoom, Whatsapp, Google Meet and Skype are used for private group sessions to allow participation and exchange within one's religious community.
} 
already frequent in the contexts of traditional African religions both in Africa and in Brazil, where religious authorities and priests attend clients and followers abroad through the aid of new technologies (Grossi 2020).

Certainly, these types of interactions continue to create tensions and debates on authenticity and ritual efficacy. However, the unprecedented sanitary crisis and the general lockdown measures revealed a sudden reassessment of online religious interactions as valid alternatives for carrying out rituals in times of social distancing.

The emergence of a "digital turn" of Afro-Brazilian religions intertwines with political stances that oppose those of the national government and its NeoPentecostal allies. These processes also have the effect of radically transforming the essential role of the body and its centrality in the ritual practice.

Indeed, this "crisis of the body" somehow puts into question the idea that physical presence is necessary in order to acquire the sacred energy and the healing properties of rituals. Social distancing allowed the proliferation of activities that were previously considered charlatanry. ${ }^{8}$ Online spiritual works, divination and healing sessions by telephone or other digital media, once considered unacceptable, are now being offered as legit strategies during the pandemic. The same applies to the transmission of ritual knowledge, once solely controlled by the elders, which is now more easily administrated by younger priests and digital natives.

As a result of the pandemic crisis and the measures of social distancing, these disputed ritual modalities are now legitimized in the cyberspace. It is possible that these strategies, considered temporary and somewhat necessary in this particular time, will set a precedent for the long-term transformation of the role of the body in Afrodiasporic religions. Moreover, this process is followed by the emergence of new virtual spaces and affordances, which will possibly play a prominent role in the development of religious experience, knowledge transmission and ritual performance in the future.

\section{Conclusion}

The Covid-19 crisis allowed Afro-Brazilian religions to be present in some online spaces that they once struggled to occupy in the past, combining social and religious values to promote a pedagogical message. Moreover, ritually related content found increasing space in the digital world. In general, we can state that during the coronavirus crisis, Afro-Brazilian religions managed to adapt and reinterpret their own values within the scientific discourses, encouraging measures of social distancing and making references to their own mythical and cosmological framework. This shift was possible despite the critical role of the body and materiality in Afro-Brazilian religions. This movement coincided with the occupation of virtual spaces that were previously dominated by the Neo-Pentecostal churches, such as social networks. In the debate on media and religion, or media as religion (Stolow 2005), media and bodies need to be understood in a continuum. The Covid-19 crisis became, for many reasons, a crisis of the body. This is not only due to the high number of deaths and infected during the

\footnotetext{
${ }^{8}$ Capponi G. 2020 (in press). "Marmotagem", in The Global Encyclopedia of Informality vol. 3. Ed. A. Ledeneva, UCL Press: London. [Online version]. https://in-formality.com/wiki/index.php?title= Marmotagem_\%28Brazil\%29 (Last accessed 16\09\2020).
} 
pandemic outbreak ${ }^{9}$ but also to the rigid measures of social distancing imposed by governments worldwide. While Neo-Pentecostal churches reacted by trying to reclaim the importance of physical attendance in the religious performance, Afro-Brazilian religions managed to find new material and mediatic affordances which continues to impact the way ritual knowledge is transmitted and the ways sacredness is experienced.

\section{Compliance with ethical standards}

Conflict of interest The authors declare that they have no conflict of interest.

\section{References}

Beliso-De Jesús AM (2015) Electric Santería. Racial and sexual assemblages of transnational religion. Columbia University Press, New York

Capponi G, Carneiro Araújo P (2015) "Eu me declaro": diálogo sobre transformações, autodefinições e reivindicações políticas nos cultos afro brasileiros, In. II Simpósio Sudeste ABHR: Gênero e religião: Violência, fundamentalismos e política, PUC/SP: São Paulo

Carneiro E (1969) Candomblés da Bahia. Rio de Janeiro: Tecnoprint

Carneiro Araújo P (2016) Ekodidé no sambódromo: segredo ritual, candomblé e espaço público no carnaval paulistano. Áltera - Revista de Antropologia 2(3):13-36

Castillo L Earl (2008) Entre a oralidade e a escrita: a etnografia nos candomblés da Bahia. Salvador: Edufba

da Silva V Gonçalves (2007) "Neopentecostalismo e religiões afrobrasileiras: significado do ataque aos símbolos da herança religiosa africana no Brasil contemporâneo", in Mana 13(1):207-237

Grossi A (2020) Religion on lockdown: on the articulation of Vodu, media and science. Religious Matters in an Entangled World. https://religiousmatters.nl/religion-on-lockdown-on-the-articulation-of-vodu-mediaand-science/. Accessed 28 Sep 2020

Hartikainen EI (2020) "Religion, law, and Bolsonaro's decree on essential services." Covid-19, Fieldsights, May 12. https://culanth.org/fieldsights/religion-law-and-bolsonaros-decree-on-essential-services. Last accessed 20 Jun 2020

Kramer WE (2005) "Spectacle and the staging of power in Brazilian Neo Pentecostalism" in: Latin American Perspectives 32 (1): 95-120

Mariano R (2004) Expansão Pentecostal no Brasil: O Caso da Igreja Universal. Estudos Avançados 18(52): $121-138$

Martini M (2020) 2020. "Interdenominational cooperation in religious new media projects: the case of the Christian Media Center”. In: International Journal of Latin American Religions 4, 137-147

Mason M Atwood (2002) Living Santería: rituals and experiences in an afro-Cuban religion. Washington DC: Smithsonian Books

Meyer B (2009) Aesthetic formations: media, religion, and the senses. Palgrave Macmillian, New York

Meyer B (2011) Mediation and immediacy: sensational forms, semiotic ideologies and the question of the medium. Soc Anthropol 19(1):23-39

Reinhardt B (2020) Atmospheric presence: reflections on "mediation" in the anthropology of religion and technology. Anthropol Q 93(1):1523-1553

Stolow J (2005) Religion and/as media. Theory Cult Soc 22(4):119-146

Van de Port M (2020) Moonlight. Mater Relig 16(1):110-112

Publisher's Note Springer Nature remains neutral with regard to jurisdictional claims in published maps and institutional affiliations.

\footnotetext{
${ }^{9}$ On the 20th June 2020, Brazil outnumbered 1 million verified cases, with more than 50.000 deaths, and the pandemic is spreading at an alarming rate
} 